\title{
MENGENAL KONFLIK AKAR PENOLAKAN DAN DAMPAKNYA DALAM MEMBANGUN RUMAH TANGGA KRISTEN
}

\author{
Pengarapen Sembiring \\ Sekolah Tinggi Teologi Baptis Medan \\ Sintha80surbakti@gmail.com
}

\begin{abstract}
In building a household, conflicts often occur, one of the biggest conflicts heard by marriage counselors in the household is a statement like the following: "My wife really doesn't understand me", or my husband never listens to me. So that makes most of the wavering marriage currently foundered experiencing divorce. Because many couples fail and do not have the ability to understand the roots of rejection experienced by their partners, or do not really know the dark past the partner can also be due to the lack of openness from the couple related to the past in the family of each partner. Negative effects will be seen after a few months or a few years in marriage then comes the original negative nature that causes anger and hatred towards the couple. The problem is not only that the impact of refusal can lead to sexual immorality or live in uncleanness in the household and even many infidelities occur because of dissatisfaction from each partner. The point in building a partner's household is not to be blind to see and pay attention to their partner enough just to fall in love to see the appearance and sympathetic nature and attention shown by their partner, but more importantly we can see the background of the past and are ready to accept all the weaknesses that are owned by his partner and completes and helps both partners to build a harmonious and happy home.
\end{abstract}

Keywords: Root of rejection; result, harmony, household.

Abstrak: Dalam membangun rumah tangga sering sekali terjadi konflik, salah satu konflik terbesar yang di dengar oleh konselor pernikahan dalah rumah tangga adalah pernyataan seperti berikut ini: “ isteri saya benar-benar tidak mengerti saya”, atau suami saya tidak pernah mendengarkan saya. Sehingga membuat sebagian besar pernikahan yang goyah saat ini kandas mengalami perceraian. Karena banyaknya pasanagan gagal dan tidak memiliki kemampuan untuk memahami akar penolakan yang di alami oleh pasanganya, atau tidak begitu mengenal masalalu yang gelap pasanganya bisa juga karena tidak adanya keterbukaan dari pasangan berkaitan masa lalu dalam keluarga masing-masing pasangan. Dampak-dampak negatif akan kelihatan setelah beberapa bulan atau beberapa tahun dalam pernikahan maka muncullah sifat-sifat asli yang negatif sehingga menimbulkan kemarahan dan kebencian terhadap pasangan. Masalah bukan hanya itu saja dampak dari penolakan bisa menibulkan percabulan atau hidup dalam kecemaran dalam rumah tangga bahkan banyak terjadi perselingkuhan karena ketidak puasan dari pasanganya masing-masing. Intinya dalam membangun rumah tangga pasangan tidak boleh buta melihat dan memperhatikan pasanganya cukup sekedar sudah jatuh cinta melihat penampilan dan sifat simpatik dan perhatian yang ditunjukkan oleh pasanganya, melainkan yang jauh lebih penting kita bisa melihat latar belakang masa lalu dan siap menerima segala kelemahan-kelemahan yang dimiliki oleh pasanganya dan melengkapi dan menolong kedua pasangan untuk membangun rumah tangga yang harmonis dan bahagia.

Kata Kunci: Akar penolakan, akibat, keharmonisan, rumah tangga. 


\section{PENDAHULUAN}

Masalah penolakan memang seringkali bisa dijumpai dalam kehidupan karena tidak ada seorang pun yang sempurna dan tidak ada manusia yang bisa memenuhi hasrat seperti yang di kehendaki oleh setiap orang. Dengan itu setiap orang bisa memberikan potensi untuk menyakiti hati orang lain dan setiap orang bisa berpotensi untuk bisa menyenangkan kehidupan orang yang lainya. Bagaimana dengan kehidupan orang yang percaya kepada Tuhan Yesus, apakah masih bisa mengalami masalah penolakan? tentu saja tidak ada orang yang bisa kebal dan terbebas dari masalah penolakan ini. Bagaimana jika masalah penolakan belum diselesaikan dalam diri seseorang?. Apa yang akan terjadi jika membangun rumah tangga?. Dengan demikian banyak keluarga yang dibangun akan mengalami banyak masalah dan rentan akan perceraian bila tidak mampu saling memahami dan saling menerima satu dengan yang lainya. Oleh sebab itu sebagai pasangan suami istri perlu memahami latar belakang atau masa lalu pasanganya masing-masing.

Menurut Kamus Besar Bahasa Indonesia arti kata 'penolakan' berarti 'dibuang; dilemparkan karna tak memiliki nilai'. Di tolak berarti menerima perkataan. Ketika hal itu terjadi pada diri seseorang, rasanya sangat menyakitan. ${ }^{1}$ Dalam konteks orang percaya, Allah tidak menciptakan manusia untuk ditolak. Ia menciptakan manusia untuk diterima, dikasihi dan dihargai. Tidak ada sesuatu dalam ciri yang diberikan oleh Allah agar manusia ditolak, namun masih banyak orang yang tidak bisa menerima orang lain atau tidak bisa diterima oleh orang lain karena alasan tertentu (Efesus 1:6).

${ }^{1}$ Anton M. Moeliono, Kamus Besar Bahasa Indonesia (Jakarta: Balai Pustaka, 1990), 500. 
Dalam mencari pasangan sering kita dengar kata-kata, 'kalau kamu menikah maka kamu perlu melihat bibit, bebet dan bobotnya.' Pernyataan ini ada benarnya bila pasangan yang akan menikah tidak melihat asal usul pasangan yang akan dinikahi, maka akan buta pengenalan dan sering sekali tidak saling mengenal dan tidak saling memahami satu dengan yang lainya. Hal ini masih sering di jumpai diberbagai daerah mereka dinikahkan karena dijodohkan oleh orang tua atau sanak saudaranya.

Sedangakan menurut James G Friesen dan E. James Wilder, tokoh konseling keluarga menuliskan pengalaman pelayanannya menangani akar penolakan adalah sebagai berikut: 'ini seorang klien di Shepherd's house menulis analogi yang mengesankan ini untuk menggambarkan bagaimana penyangkalan masa lalu telah melumpuhkanya. Masa lalu yang tidak diselesaikan telah menghalangi hubunganya dengan orang lain bahkan dengan Allah dan membawanya kepada keterasingan yang memilukan. ${ }^{2}$

Jadi pentingya memahami masalah penolakan sebagai peminpin rohani dan orang percaya agar bisa menolong dan membantu keluarga-keluarga atau orang-orang yang mengalami atau yang memiliki masalah dalam masa lalu khususnya dalam penolakan. Sehingga bisa memberikan bantuan dan pendampingan konseling yang efektif dan memberikan penanganan pemulihan sehingga dapat tuntas. Oleh sebab itu pentingya memahami sebab dan akibat yang akan terjadi bila seseorang memiliki akar penolakan baik dalam diri sendiri

2 James G. Friensen dan E. James Wilder, Seri Konseling; Hidup Dari Hati Yang Di Berikan Yesus (Bandung: Kalam Hidup, 2005), 30. 
maupun keluarga. Sehingga ciri-ciri orang yang mengalami penolakan yang bermasalah dalam dirinya bisa ditolong oleh para Konselor Kristen.

\section{METODE}

Metode penelitian tulisan ini dilakukan dengan metode kualitatif. Melalui penelitian ini penulis memilih pendekatan penelitian kualitatif. Metode ini sering juga disebut metode artistik, karena proses penelitian ini lebih bersifat seni (kurang terpola) dan disebut sebagai metode interpretive, karena data hasil penelitian lebih berkenaan dengan interprestasi terhadap data yang ditemukan di lapangan. Dengan metode kualitatif dapat ditemukan data-data yang berserakan, selanjutnya dikonstruksikan dalam suatu tema yang lebih bermakna dan mudah di pahami.

Penulisan penelitian ini menggunakan metode deskritif - analitis, artinya penyelidikan yang tertuju pada pemecahan masalah melalui pemaparan dan penafsiran fakta tentang pokok bahasan. Sedangkan analitis, karna fakta tentang pokok bahasan yang dikumpulkan, disusun, dijelaskan dan dianalisa. ${ }^{3}$ Prosedurnya, untuk memperoleh data yang ilmiah dan akurat, penulis mengumpulkan data / fakta yang berkaitan dengan pokok pembahasan Megenai Konflik Akar Penolakan dan dampaknya dalam membangun rumah tangga Kristen. Melalui studi literatur, Alkitab, buku - buku, artikel Jurnal dan karya tulis yang yang berkenaan dengan teologi, psikologi konseling maupun sosial budaya. Dalam semuanya itu, Alkitab menjadi satu-satunya sumber utama wawasan teologis yang Alkitabiah guna memberikan usulan yang benar berkaitan dengan penelitian dan menemukan jalan penyelesaiannya.

3 Sukarman, Metode Penelitian (Bandung: Alfabeta, 1998), 139-140. 
Penulisan ini juga melakukan penelitian tinjauan kepustakaan dan dengan menggunakan metode studi deskriptif. Menurut Sugiyono pendekatan kualitatif ini digunakan untuk mendapatkan data mendalam, suatu data yang mengandung makna. Dalam penelitian kualitatif bersifat menemukan teori. Alasan penulis memilih metode ini adalah karena permasalahan belum begitu jelas, holistik, kompleks, dinamis dan penuh makna sehingga tidak mungkin data pada situasi tersebut dibahas dengan metode penelitian kuantitatif. ${ }^{4}$ Metode ini akan melakukan lewat wawancara kepada 4 orang keluarga yang memiliki masalah korban dalam akar penolakan.

\section{HASIL}

Dari hasil penelitian, akar penolakan ini memiliki kecenderungan mengulang kembali kepada pengalaman masa lalunya sehingga berpotensi besar diturunkan kepada anak-anaknya juga akan menerima akar penolakan, dan berpotensi untuk melukai orang-orang yang memiliki hubungan dekat dengan korban akar penolakan. Disebabkan karena masih adanya rasa marah, benci dan tidak menerima dirinya di rendahkan dan ditolak, maka sering sekali emosinya tidak stabil, rasa marah dan dendam yang begitu lebih kuat sehingga kecenderunganya membalaskan dendam emosinya. Hal ini berdampak negatif jika orang lain tidak mengetahui masalah masa lalunya yang mengalami akar penolakan, sedangkan si korban penolakan akan melukai kepada siapa saja yang ada disekitarnya.

${ }^{4}$ Sugiyono, Metode Penelitian Kuantitatif dan Kualitatif dan Kombinasi (Bandung: Alfabeta, 2012), 
Selanjutnya seorang korban yang mengalami masalah akar penolakan akan sering membawa masalah dilingkunganya yang membawa rasa pemberontakan, permusuhan dan perpecahan serta keributan dilingkungan dimana saja dia berada. Serta kecenderungan kurang memiliki gambar diri yang baik, kurang percaya diri dan suka iri serta membandingkan kehidupan dirinya dengan orang lain. Kecenderungan bersifat otoriter / kasar, egois, ingin menang sendiri, tidak menerima nasehat, koreksi dan teguran. Bahkan kurang menghargai orang lain dan suka merendahkan orang lain bahkan tidak berani mengakui kesalahannya maka selalu menyalahkan orang lain yang dapat disalahkan.

Perlunya melakukan rekonsiliasi bagi korban akar penolakan sehingga mendapatkan pemulihan dalam hidup. Melalui memperdamaikan hubungannya dengan Tuhan selanjuntnya memperdamaikan dirinya dengan orang-rang yang melukainya, sehingga mampu mengampuni dan memilih untuk membangun dirinya sebab masa lalu tidak bisa diubah lagi, sedangkan masa depan hidup kita harus kita membaharuinya di dalam Tuhan, sehingga hidup bebas dari masalah akar penolakan, hidup penuh dengan kebahagiaan dan sukacita menjalaninya.

\section{PEMBAHASAN}

Setiap orang pasti pernah mengalami penolakan, atau setiap orang tidak ada yang tidak pernah ditolak oleh orang lain, mungkin penolakan dilakukan oleh keluarga, orang tua, saudara-saudari, teman teman sepermainan, teman-teman di sekolah dam lain-lain Penolakan bisa juga dialami pada saat kita berada ditempat kita kerja yang dilakukan mungkin oleh peminpin dalam perusahan atau tempat dimana orang itu bekerja. 
Dalam dunia pelayanan kerohanian atau rohani juga tidak bebas dari penolakan, sering terjadi penolakan yang dialami oleh Pendeta atau peminpin rohani ketika ditempatkan dalam suatu tempat pelayanan yang baru, misalkan ditempatkan sebagai pendeta dalam Gereja tertentu. Namun bisa jadi jemaat tidak suka kepada seorang pendeta yang baru ditempatkan di Gereja, karena berbagai alasan yang tidak sama dengan pendeta atau peminpin yang baru di tempatkan itu. Bisa jadi peminpin atau majelis menolak atau tidak suka dengan pendeta atau peminpin yang baru ditempatkan di Gereja atau Lembaga - lembaga Rohani yang ditempatkan. Oleh sebab itu sangat penting bagi seorang pemimpin dan hamba Tuhan dan setiap orang untuk memahami tentang masalah akar dari penolakan agar mampu mengatasi dan memanagemen konflik yang ada ketika diperhadapkan dengan masalah penolakan.

Menurut Ted Ward dalam bukunya Nilai Hidup Dimulai Dari Keluarga mengatakan bahwa melalui pengalaman-pengalaman dalam keluarga kita belajar banyak tentang nilai-nilai yang paling penting. Lingkungan keluarga sangat berpengaruh dalam membentuk dan menetapkan nilai-nilai. ${ }^{5}$ Dengan demikian jika ada seseorang atau pasangan yang mengalami penolakan dalam keluarganya pada waktu masa kecil, atau masa kandungan dan mungkin sesudah dilahirkan akan membentuk dalam diri si korban penolakan, merasa nilai dirinya rendah dan merasa tidak berharga. Karena selama ini diperlakukan dan dianggap tidak ber nilai dalam keluarga. Sebab sebagaimana seseorang diperlakukan maka kebanyakan orang menganggap seperti itulah nilai dan harga diri seseorang.

5 Ted Ward, Nilai Hidup Mulai Dari Keluarga (Malang: Gandum Mas, 1976), 9. 
Menurut John C. Maxwell dalam tulisanya Running With The Giants dalam pokok Nasehat para raksasa iman Perjanjian Lama tentang hidup dan kepeminpinan Daud bagaimana dia juga mengalami penolakan dan direndahkan mengatakan bahwa:

Pertama, Isai tidak merasa Daud menjadi Raja, oleh sebab itu ketika Nabi Samuel akan mengurapi salah satu putranya, Daud tidak dianggap berpotensi menjadi raja untuk dipilih oleh Allah sehingga Daud di padang untuk mengembalakan domba ayahnya. Isai menunjukan tujuh putranya kepada Nabi Samuel. Kedua, saudara-saudara Daud tidak merasa Daud berkemampuan berperang, Daud mengalami penolakan dari para kakak lelakinya yang menjadi perajurit untuk melawan filistin dan ketika Daud datang Kakanya Eliab berkata "mengapa engkau datang? Kepada siapakah kau tinggalkan kambing domba yang dua tiga ekor itu di padang gurun? Aku kenal sifat pemberanimu dan kejahatan hatimu, engkau datang kemari dengan maksud melihat pertempuran" (1Sam.17:28). Kakaknya Daud melihat dia hanya sebagai seorang pesuruh. Ketiga, Raja Saul tidak berpikir bahwa Daud mempunyai kemampuan menjadi Raja (1Sam. 17:3233). Sehingga Daud dipakaikan baju perangnya raja Saul. Keempat, Goliat tidak merasa berkemampuan sebagai musuh (1Sam.17:43-44). Jadi Daud mengalami penolakan dari keluarganya (pembatasan keluarga), mengalami penolakan Raja Saul (pembatasan kepeminpinan), penolakan melalui Goliat (pembatasan keterampilan). ${ }^{6}$

Sering sekali pengalaman-pengalaman yang dialami oleh raja Daud ini menjadi pengalaman pengalaman setiap peminpin atau orang percaya, dimana setiap orang percaya memiliki latar belakang yang buruk dan pengalaman yang buruk. Mereka diperlakukan dalam keluarga asalnya yang merendahkanya, mungkin karena orang tuanya bercerai, keterbatasan / kekurangan finansial dan lain sebagainya, bisa jadi keadaan orang yang percaya ditolak oleh Pemimpinya sendiri atau direndahkan karena kurangnya kemampuan dan keterampilan yang dimiliki.

${ }^{6}$ John C. Maxwell, Runing with the Giants (Jakarta: BPK Gunung Mulia, 2011), 117. 
Selanjutnya Joyce Meyer dalam bukunya Akar Dari Penolakan, menuliskan sebab - sebab orang mengalami akar penolakan adalah sebagai berikut ini :

1. Bayi kandungan yang tidak diingini. 2. Hasil niat, usaha melakukan aborsi. 3. Seorang anak yang dilahirkan salah; keinginan anak laki-laki tapi lahir perempuan dan sebaliknya. 4. Anak cacat fisik. 5. Membandingbandingkan dengan saudara kandung. 6. Adopsi. Diabaikan.(anaknya banyak) kurang kasih sayang. 7. Mengalami kematian / salah satu org tua di masa kecil. 8. Kekerasan; bersifat fisik, kata-kata, seksual,emosional, kasih yg tidak di sampaikan / diungkapkan. 9. Menjadi korban keadaan, miskin, sakit berkepanjangan. 10. Kekacauan dalam rumah tidak berfungsinya peran ayah dan peran ibu dalam rumah tangga. 11. Penolakan dari kawan sebaya. 12. Penolakan pernikahan, ketidak setiaan, perceraian. ${ }^{7}$

Sedangkan Theresia Hutahuruk menuliskan tentang kesembuhan luka batiniah menurut Alkitab. Mengatakan bahwa proses luka batin dan akar pahit mengatakan bahwa:

Pertama, bahwa kurang percaya diri mengakibatkan rasa malu dan menutup diri. Kejadian 3: 7 menuliskan "maka terbukalah mata mereka berdua dan mereka tahu, bahwa mereka telanjang; lalu mereka menyemat daun pohon ara dan membuat cawat. Kedua, hati orang yang terbuang (rasa tertolak) mengakibatkan sakit dan sulit di percaya (Kej. 3: 14-24). Ketiga, hati yang lapar dengan kasih. Kej. 4: 1-5. Keempat, hati yang marah. Kej. 4: 5-15. Kelima, keempat macam hati tersebut menunjukkan keaslian hati manusia sesungguhnya yang telah menjadi sakit dan rusak karena manusia pertama sudah jatuh ke dalam dosa. ${ }^{8}$

Hal di atas memberikan keterangan yang sangat jelas berkaitan dengan ciri-ciri seorang yang mengalami akar penolakan. Orang yang mengalaminya sulit untuk bersukacita karena derita yang dialami di dalam batin seseorang. Sehingga sebagai konselor dan peminpin rohani bisa mengenali orang-orang yang dilayaninya sehingga dapat membimbing dan mendampingi dengan baik dan efektif.

7 Joyce Meyer, Akar Dari Penolakan (Batam: Nafiri Ekspress, 2001), 30-31.

8 Theresia Hutahuruk, "Kesembuhan Luka Batiniah menurut Alkitab," Illuminate: Jurnal Teologi dan Pendidikan Kristiani 1, no. 1 (2018). 


\section{Memahami Dapak-Dampak Akibat Masalah Penolakan Merusak Hubungan Suami-Isteri}

Dalam Mazmur 27: 10, berkata 'sekalipun ayahku dan ibuku meninggalkan aku, namun Tuhan menyambut aku (mengangkatku jadi sebagai anaknya). Artinya, walaupun ibu dan ayah pergi meninggalkan, tetapi Tuhan akan menyambut dan mengangkat orang percaya sebagai anak-Nya sendiri. Ini merupakan ungkapan Raja Daud sebagai orang yang mempunyai pengalaman mengenai penolakan dalam kehidupanya. Mengalami pengalaman yang sulit namun Tuhan Allah yang mengangkat dan menerimanya sebagai orang yang menyenangkan hati Tuhan karena Daud menjadi sahabat Tuhan dan menjadi Anak Tuhan sehingga Allah berjanji dari keturunanya Mesias akan di lahirkan.

Joyce Meyer dalam bukunya Akar Dari Penolakan mengatakan bahwa dampak-dampak akibat dari penolakan adalah sebagai berikut: Pemberontakan, kemarahan, kepahitan, rasa bersalah, rendah diri, gambar diri yg rusak, suka menghayal, berangan-angan, kecanduan obat, alkohol, televisi, pekerjaan, suka menghakimi, Kemiskinan, Berbagai jenis rasa takut, keputusasaan, pembelaan diri, kekerasaan, ${ }^{9}$ ketidakpercayaan, tidak menghargai, kompetisi - merasa saingan / musuh, kecemburuan, perfeksionis / kesempurnaan.

Selanjutnya dari pernyataan-pernyataan di atas dijelaskan bahwa akan banyaknya dampak yang buruk bagi orang yang mengalami akar penolakan dalam setiap kehidupan orang yang mengalaminya. Sehingga jika tidak terselesaikan, maka akar penolakan itu akan di bawanya ketika membangun rumah tangganya. Sehingga ini akan sulit untuk membangun hubungan komunikasi serta

${ }^{9}$ Meyer, Akar Dari Penolakan, 34-35. 
membangun rumah tangga karena memiliki akar-akar yang pahit dalam diri seseorang. Sehingga banyak keluarga tidak bahagia dan banyak yang mengalami perceraian akibat masa lalu yang pahit, hal tersebut akan tercermin lewat perkataan dan tindakanya juga saling melukai dan menyakiti pasangannya.

Oleh sebab itu ketika seseorang memiliki luka dalam diri, hal tersebut akan berdampak ketika dia membangun hubunganya dengan seseorang, terlebih lagi ketika membangun rumah tangga maka tidak bisa membangun hubungan yang baik dengan pasanganya, serta akan berpengaruh juga terhadap seorang korban dari penolakan. Ia juga akan sulit membangun hubunganya dengan Tuhan Allah, sehingga akan mebawa beban bagi dirinya sendiri serta membawa seseorang itu kepada kesendirian dan kesepian karena sulit baginya untuk menerima atau percaya kepada orang yang lain.

Dari hal ini masalah penolakan yang dialami oleh setiap orang bukanlah hal yang tabu dan memalukan, karena bisa jadi setiap orang percaya bisa mengalami pengalaman yang buruk, pernah mengalami masalah penolakan yang melukai hati atau masa lalu diperlakukan dengan tidak baik serta direndahkan sehingga merasa tidak berharga. Tetapi siapa saja bisa mengalaminya baik lapisan masyarakat kalangan bawah, menengah dan masyarakat golongan kaum atas. Oleh sebab itu setiap orang percaya bisa mengalami kesembuhan dan pemulihan dalam hidupnya.

\section{Solusi Dan Rekomendasi Untuk Memulihkan Pasangan Yang Mengalami Akar Penolakan Dalam Keluarga}

Bagian ini adalah yang sangat penting, Bagaimana seorang percaya yang mengalami akar penolakan dapat memperoleh kemenangan atas derita 
penolakan?. Menurut Dennis \& Metthew Linn dalam bukunya Penyembuhan Luka-Luka Batin beberapa saran dan solusi untuk menolong adalah sebagai berikut ini. Pertama, perlunya menyadari dan mempelajari riwayat kehidupan dalam keluarga. Kedua, menerima yang terjadi. Belajar bersyukur dan mengucap syukur. Ketiga, mengampuni masa lalu - diri, orang lain, peristiwa yang prnah terjadi. ${ }^{10}$

Sedangkan menurut John C. Maxwel mengatakan ada 3 cara: 1. Keterbatasan tidak membatasasi kecuali mengizinkanya. 2. Jangan mencoba menjadi orang lain, ketika orang-orang memaksakan pembatasan. 3. Ketika bertumbuh melampaui keterbatasan dapat menolong orang lain melakukan hal yang sama. $^{11}$

Bagaimana menangani dan menolong orang yang mengalami korban dari akar penolakan agar dapat bergerak maju dan berkembang serta bisa melihat masa depan dan tidak melihat ke masa lalunya lagi?. Berikut adalah saran-saran yang bisa menolong seperti yang dijelaskan oleh Norman Wright, Konseling Krisis : Kembangkan kompetensi diri (self competence), Pengetahuan - pendidikan, belajar., Emosional - kecerdasan emosi, Spiritualitas - iman, relasi dengan Tuhan. Sosial \& kultural- kerja, relasi, komunikasi. ${ }^{12}$

Berikut ini adalah saran-saran yang sudah ampuh dapat menolong banyak orang yang menjadi korban penolakan untuk bangkit dan berkompetensi di dalam bidangnya dan tempat dimana seorang mengalami perubahan yang signifikan dan membawa dampak yang positif perubahan sehingga banyak orang mengalami perubahan hidup semakin baik dan sehat melihat dan memandang tentang

\footnotetext{
10 Dennis dan Matthew Linn, Penyembuhan Luka-Luka Batin (Yogyakarta: Kanisius, 1993), 105.

${ }_{11}$ Maxwell, Runing with the Giants, 125.

12 Norman Wright, Konseling Krisis (Malang: Gandum Mas, 1993), 75.
} 
identitas dan bisa membangun nilai harga dirinya dengan positif. Hal-hal di atas sejalan dengan Rika Kartika yang mengatakan bahwa hal-hal praktis yang perlu dilakukan untuk membangun keharmonisan keluarga sebagai berikut; sikap saling percaya, membangun pertalian, kepuasan dalam komunikasi, kejelasan isi percakapan dan dukungan. ${ }^{13}$

\section{Solusi Masalah Akar Penolakan Menurut Firman Tuhan}

Bagaimana solusi-solusi yang di paparkan firman Tuhan untuk menolong orang-orang yang menjadi korban dari penolakan?. Berdasarkan firman Tuhan sebagaimana setiap orang yang menjadi korban penolakan akan menghadapi konsekwensi. Oleh sebab itu perlu sikap bersyukur (1Tes. 5: 18; Ef. 5: 19 ; Rom. 8:28). Setiap orang yang mengalami penolakan mampu melihat rencana Tuhan yang indah dan selalu baik bagi setiap anak-anak-Nya.

Selanjutnya sebagai orang yang percaya kepada Kristus memiliki identitas yang baru sebagai anak-anak Allah (Yoh. 1: 12; 2Kor. 5: 17). Sebagai umat Allah semestinya menyadari dan mengalami bahwa setiap orang dikasihi oleh Allah seperti yang tertulis di dalam Yohanes 3: 16 "Karena begitu besar kasih Allah akan dunia ini sehingga Ia telah mengaruniakan Anak-Nya yang tunggal. Supaya setiap orang yang percaya kepada Nya tidak akan binasa melainkan beroleh hidup yang kekal". ${ }^{14}$

Dalam Yesaya 43: 4 Mengatakan bahwa karena engkau berharga dan mulia dalam pandangan $\mathrm{Ku}$, dan Aku ini mengasihi engkau maka Aku akan memberikan manusia sebagai gantimu, dan bangsa-bangsa sebagai ganti 
nyawamu. Setiap orang percaya perlunya bertumbuh secara iman. Dalam Yesaya $61: 1-3$, Sebagai orang percaya mestinya memiliki pohon kehidupan yang sehat dan berbuah, bukan pohon yang sakit dan terluka sehingga tidak menghasilkan buah apa-apa.

Dari pembahasan topik-topik ini dan dari kebenaran firman Tuhan sudah seharusnya setiap orang yang percaya dan setiap keluarga-keluarga Kristen mestinya memberikan buah dalam kehidupanya. Maka setiap orang percaya dan keluarga yang percaya hendaknya memberikan buah-buah yang manis bagi Kerajaan Allah, karena dalam kehidupanya bertumbuh dengan sehat dan kuat membawa rumah tangga yang harmonis dan bahagia serta menghasikan anak-anak yang sehat secara jasmani dan rohani. Sebab setiap orang yang percaya dipanggil menjadi pohon yang sehat dan tidak lagi terluka dan trauma karena kepahitan dari akar penolakan. Tetapi setiap orang yang percaya dan keluarga Kristen terpanggil untuk menghasikan buah, baik itu buah pertobatan, Buah Roh Kudus serta buahbuah jiwa yang di persembahkan bagi Kristus Tuhan sebagai ucapan syukur oleh karna sudah diselamatkan oleh Anugrah Allah.

\section{KESIMPULAN}

Masalah dalam akar penolakan yang di perhadapkan kepada setiap orang timbul karena kurangnya mendapatkan kasih sayang serta kurangnya penerimaan yang dilakukan oleh keluarga, lingkungan sekitar dan teman sepermainan. Sehingga pengalaman masa lalu yang buruk yang melukai hati dan batin seseorang, akibat kurangnya penghargaan diri oleh orang lain dapat menimbulkan paradigma yang negatif terhadap diri sendiri. 
Dengan demikian, bisa dipahami bahwa tidak ada orang yang benar-benar kebal jika diperhadapkan dengan masalah akar penolakan dalam hidupnya. Sebab tidak ada keluarga yang sempurna atau tidak ada seorang pun yang sempurna, seperti Rasul Paulus katakan dalam kitab Roma 3: 23 "karena semua orang telah berbuat dosa dan kehilangan kemuliaan Allah." Bisa jadi seseorang mengalami akar penolakan dikeluarganya akibat masa lalu di dalam keluarga seperti ayah atau ibunya menjadi korban penolakan dalam keluarga, lingkungan, atau teman sepermainanya yang sangat melukai hatinya, hal ini akan menimbulkan masalah kepada Anak-anaknya, akan membawa masalah kepada istrinya serta dalam membangun hubungan dengan sesama, sehingga di dalam dirinya / hatinya yang terluka sangat berpotensi untuk melukai hati sesamanya. Karena belum mengalami pemulihan hati dan belum dapat mengampuni dan menyelesaikan masalah penolakanya. Selain itu seseorang yang mengalami akar penolakan akan sulit baginya membangun hubungan yang intim dengan Allah, sehingga hubungan dan persekutuanya dengan Tuhan tidak akan bisa bertumbuh secara sehat dalam iman.

Oleh sebab itu akar penolakan ini, sangat perlu untuk dipahami oleh setiap orang yang percaya dan khususnya sebagai pelayan Tuhan sehingga sebagai pemimpin Rohani dapat menolong dan memulihkan serta memberikan pendampingan bimbingan konseling sampai mengalami kesembuhan dan pulih dari setiap lukanya.

Biasanya luka akar penolakan dapat dikenal gejala yang terjadi oleh 12 sebab yakni: 1. Bayi kandungan yang tidak diingini. 2. Hasil niat, usaha melakukan aborsi. 3. Seorang anak yang dilahirkan salah; keinginan anak laki-laki 
tapi lahir perempuan dan sebaliknya. 4. Anak cacat fisik. 5. Membandingbandingkan dengan saudara kandung. 6. Adopsi, diabaikan (anaknya banyak) kurang kasih sayang. 7. Mengalami kematian/salah satu orang tua di masa kecil. 8. Kekerasan; bersifat fisik, kata-kata, seksual, emosional, kasih yang tidak di sampaikan/diungkapkan. 9. Menjadi korban keadaan, miskin, sakit berkepanjangan. 10. Kekacauan dalam rumah, tidak berfungsinya peran ayah dan peran ibu dalam rumah tangga. 11. Penolakan dari kawan sebaya. 12. Penolakan pernikahan, ketidaksetiaan, perceraian.

Sedangkan dampak yang ditimbulkan dari akar penolakan adalah sebagai berikut: Pemberontakan, kemarahan, kepahitan, rasa bersalah, rendah diri, gambar diri yg rusak, suka menghayal, berangan-angan, kecanduan obat, alkohol, televisi, pekerjaan, suka menghakimi, Kemiskinan, Berbagai jenis rasa takut, keputusasaan, pembelaan diri, kekerasaan, Ketidak percayaan, tidak menghargai, kompetisi- merasa saingan/musuh, kecemburuan, perfecksionisme/kesempurnaan.

Dengan demikian paparan yang di paparkan dari masalah dari akar penolakan bukanlah suatu aib yang memalukan jika seseorang menjadi korban atas penolakan dalam dirinya, sebab banyak orang yang percaya malu dan tidak mau terbuka dengan masa lalunya yang sudah menimbulkan kepahitan dalam hatinya. Jika tetap bertahan menyimpan kebencian dan rasa sakit hati, maka tidak mengalami kesembuhan dan pemulihan dalam hidup. Sehingga tidak menghasilkan kualitas iman yang bertumbuh sehat dan mengalami banyak perubahan-berubahan dalam hidup yang nyata dialami. 
Sebagai korban penolakan perlunya komitmen-komintmen yang di ambil sehingga menyadari keberadaan akar penolakan yang di alami serta mau membuka hati dan mengakui segala dosa kepada Tuhan Yesus untuk bertobat mau berdamai serta menerima keadan dan apa yang sudah terjadi dalam hidupnya. Sebagai peminpin rohani atau pelayan maka perlunya keterampilan untuk menangani dengan mempelajari teori dan menolong korban dari akar penolakan untuk dikonseling dan disembuhkan dan dipulihkan kembali sehingga korban dapat bangkit dan memandang dengan mengarahkan kehidupan yang akan dibentuk lewat masalah-masalah dalam kehidupan masing-masing yang berbeda.

Maka dalam karya tulis ini diberikan beberapa cara dan metode pendekatan untuk menolong para korban yang mengalami akar penolakan, baik secara Teologi dengan pendekatan berdasarkan firman Tuhan dan hal-hal praktis /pelayanan prekatis yang dapat dilakukan. Pemulihan hidup adalah kehendak Allah bagi setiap orang yang percaya sehingga melalui hidup orang percaya yang dipulihkan dan hidup yang sudah dibaharui serta diubahkan akan menjadi sebuah kesaksian yang hidup. Sehingga setiap orang lain juga yang memiliki masalah khusus akar penolakan yang di alami dari keluarga, lingkungan, dan teman sepermainan bisa dipulihkan, dari jerat tipu daya setan yang membelenggu mereka khususnya berkaitan dengan kesakitan karena akar penolakan. Dengan demikian pemulihan seseorang dari lukanya akan sangat berdampak ketika membangun rumah tangganya, maka akan menjadi keluarga yang bahagia dan harmonis dalam kasih karunia Tuhan tanpa ada lagi luka-luka dan kepedihan yang tersembunyi di dalam hati mereka. Oleh sebab itu satu orang yang sungguhsungguh mengalami pemulihan akan membawa buah dan dampak yang membawa 
perbedaan / perubahan dan terang Kristus atau kabar yang baik akan nyata bagi keluarga, lingkungan dan teman sepermainanya. Sebab bagi Allah tidak ada yang mustahil. Jikalau orang lain Tuhan Yesus pulihkan maka setiap orang yang datang dan berbalik ke padaNya dengan membawa lukanya akan mengalami Kasih dan Kuasa Allah yang Ajaib.

\section{DAFTAR PUSTAKA}

Dennis, dan Matthew Linn. Penyembuhan Luka-Luka Batin. Yogyakarta: Kanisius, 1993.

Friensen, James G., dan E. James Wilder. Seri Konseling; Hidup Dari Hati Yang Di Berikan Yesus. Bandung: Kalam Hidup, 2005.

Hutahuruk, Theresia. "Kesembuhan Luka Batiniah menurut Alkitab." Illuminate: Jurnal Teologi dan Pendidikan Kristiani 1, no. 1 (2018).

Kartika, Rika. "Membangun Keharmonisan Keluarga." Jurnal Teologi Syalom 5, no. 1 (t.t.).

Maxwell, John C. Runing with the Giants. Jakarta: BPK Gunung Mulia, 2011.

Meyer, Joyce. Akar Dari Penolakan. Batam: Nafiri Ekspress, 2001.

Moeliono, Anton M. Kamus Besar Bahasa Indonesia. Jakarta: Balai Pustaka, 1990.

N, N. Alkitab. Jakarta: LAI, 2005.

Sugiyono. Metode Penelitian Kuantitatif dan Kualitatif dan Kombinasi. Bandung: Alfabeta, 2012.

Sukarman. Metode Penelitian. Bandung: Alfabeta, 1998.

Ward, Ted. Nilai Hidup Mulai Dari Keluarga. Malang: Gandum Mas, 1976.

Wright, Norman. Konseling Krisis. Malang: Gandum Mas, 1993. 